The stroke was $10 \mathrm{ft}$. There were five piston rods in all, carrying an overhead weight of more than 80 tons and connected to eight great beams disposed radially about the cylinder. From the outer ends of the beams hung the pump rods and pump buckets. Each pump barrel was $6 \mathrm{ft}$. in diameter and had a stroke of $10 \mathrm{ft}$. The engine is installed in a fine round castellated building surrounded by a platform with a parapet, and the whole undoubtedly forms the most imposing historical example of pumping machinery in the world, and one which we are sure will attract the attention of many visitors to Holland.

\section{German Sterilisation Laws}

RECENT German legislation on eugenic sterilisation is described by Dr. Aubrey Lewis in the Eugenics Review (Oct. 1934, p. 183), especially as regards the ordinances issued by the Ministers for Home Affairs and for Justice, and the semi-official commentary of Rüdin, Gütt and Ruttke. Voluntary sterilisation is precluded except for the diseases for which sterilisation is compulsory, and carriers of a hereditary disease may not be sterilised voluntarily. If an appeal is lodged against a sterilisation order, the patient must be detained until his case is disposed of. The physician must report every relevant case encountered in his professional work, but all information collected by the Psychiatric Research Institute is strictly confidential. Overcrowding of the mental hospitals is resulting from the administrative delays. The total population of mental institutions in Germany is reckoned at 160,000 , of which 36,000 will probably undergo sterilisation. However, Roemer, an influential psychiatrist, estimates that 400,000 people in Germany are envisaged for sterilisation, 360,000 of which are psychiatric cases. In the same journal (p. 211) Dr. F. Tietze gives an account of the Austrian sterilisation trial at Graz, in which the supreme court reversed the decision of the provincial court and condemned the defendants to imprisonment for practising or advocating eugenic sterilisation, on the ground that the consent of the individual did not exclude 'hostile intention' or change the character of a sterilising operation.

\section{U.S. Petroleum Industry}

The review of the petroleum industry in the United States by Hale B. Soyster and members of the U.S. Geological Survey, Bureau of Mines and Petroleum Administrative Board, recently published by the U.S. Department of the Interior (Circular 11), gives an authoritative, unbiased survey of the American petroleum industry to-day, besides supplying up-to-date statistics of production, stocks, imports and exports. A vital fact is that petroleum reserves, both proved and unproved, are limited and irreplaceable. Wastage, whether physical or economic, is to be deplored and must be combatted with carefully planned and controlled development of all supplies. Latterly, knowledge of methods of preventing waste of both oil and gas and conserving natural energy necessary for recovery of these substances, has rapidly increased, but there are still varied forms of economic waste, to some of which it is difficult to find a solution. Competitive development and premature extraction of petroleum still characterise a majority of new fields and will continue to do so as long as the theory of 'capture and reduction to possession' holds sway.

Wттн petroleum increasingly incident in tho industrial life of the nation, particularly as motor fuel, and with the knowledge that reserves are limited, it is natural that extensive researches should be prosecuted to find substitutes in the event of shortage. After consideration of possibilities of highand low-temperature carbonisation, hydrogenation and complete gasification of coal, the most feasible method for large-scale production of gasoline, should petroleum resources decline rapidly in the future, is that of hydrogenation and liquefaction. During this process, however, more original fuel energy is lost than in making gasoline from petroleum, and the cost of gasoline produced is higher. The reassuring fact that processes are available for producing motor fuel substitutes from coal is no excuse for wasteful exploitation of present oil reserves. Coal should be used wherever possible for ordinary heating and stationary power generation, and petroleum strictly conserved in all phases of its production and refinement to avoid the necessity of producing gasoline from coal by an elaborate and expensive process.

\section{Bulk Supply of Electric Power for Manufacturers}

SheFField CoRporation has now connected up what is probably the largest individual user of electricity in Great Britain to its supply mains, increasing the supply by more than thirty per cent. Messrs. Thomas Firth and John Brown, Ltd., of Sheffield, have works covering 140 acres, and formerly had two generating stations of their own having a capacity of 20,000 kilowatts. Now they have abandoned these, and obtain energy from the public supply mains. Generally speaking, there are many reasons for taking this course. They will be able, for example, to concentrate on their own particular processes of production, leaving the generation of electricity to experts. The space formerly occupied by the boilers and turbines of the private plants can now be utilised for extensions. The basis of the manufacturing processes carried out by the firm are in the melting house, where there are installed furnaces ranging from a capacity of 2 tons to 40 tons. The largest furnace, when melting at its peak load, requires 5,000 kilovolt amperes. The electric furnaces alone melt 1,000 tons per week. This is much greater than the output of any other electric furnace plant in Great Britain. All the supply problems are now dealt with by the Corporation engineers, who have the Grid behind them as a reserve. The bulk supply is given to the works at 33,000 volts, and the distribution is so operated that the lowest possible simultaneous demand is made. The decision reached by this firm to take the public supply will carry great weight with other companies which are considering the problem of continuing to manufacture their own electric power or not. 